\title{
Hydrogen peroxide produced by Aplysia ink toxin kills tumor cells independent of apoptosis via peroxiredoxin I sensitive pathways
}

\author{
D Butzke ${ }^{1,2}$, N Machuy $^{2}$, B Thiede ${ }^{2}$, R Hurwitz ${ }^{3}$, S Goedert ${ }^{2}$ and \\ T Rude $^{\star, 2}$ \\ ${ }^{1}$ Institut fuer Oekotoxikologie und Biochemie der Freien Universität Berlin, \\ Ehrenbergstr. 26-28, Berlin, Germany \\ 2 Max-Planck-Institut für Infektionsbiologie, Abteilung Molekulare Biologie, \\ Berlin, Germany \\ ${ }^{3}$ Max-Planck-Institut für Infektionsbiologie, Serviceabteilung Proteinreinigung, \\ Berlin, Germany \\ * Corresponding author: T Rudel, Department of Molecular Biology, Max- \\ Planck-Institute for Infection Biology, Schumannstr. 21/22, D-10117 Berlin, \\ Germany. Tel.: + 493028460 415; Fax: + 493028460 401; \\ E-mail: rudel@mpiib-berlin.mpg.de
}

Received 14.7.03; revised 20.10.03; accepted 27.11.03; published online 06.2.04 Edited by SA Lipton

\section{Abstract peroxidase involved in the detoxification of peroxides. for tumor therapy. \\ Cell Death and Differentiation (2004) 11, 608-617. \\ doi:10.1038/sj.cdd. 4401385 \\ Published online 6 February 2004}

Marine snails of the genus Aplysia possess numerous bioactive substances. We have purified a $60 \mathrm{kDa}$ protein, APIT (Aplysia punctata ink toxin), from the defensive ink of $A$. punctata that triggers cell death with profound tumor specificity. Tumor cell death induced by APIT is independent of apoptosis but is characterized by the rapid loss of metabolic activity, membrane permeabilization, and shrinkage of nuclei. Proteome analysis of APIT-treated tumor cells indicated a modification of peroxiredoxin I, a cytoplasmic Interestingly, knockdown of peroxiredoxin I expression by RNA interference sensitized cells for APIT-induced cell death. APIT induced the death of tumor cells via the enzymatic production of $\mathrm{H}_{2} \mathrm{O}_{2}$ and catalase completely blocked APITs' activity. Our data suggest that $\mathrm{H}_{2} \mathrm{O}_{2}$ induced stress and the modulation of peroxiredoxins might be a promising approach

Keywords: oxidative stress; tumor; peroxiredoxin; $\mathrm{H}_{2} \mathrm{O}_{2}$; L-amino-acid oxidase; RNA interference

Abbreviations: APIT, Aplysia punctata ink toxin; chx, cycloheximide; PBMC, peripheral blood mononuclear cells; PI, propidium iodide; Prx I, peroxiredoxin I; RNAi, RNA interference; ROS, reactive oxygen species.

\section{Introduction}

Marine sea hares produce purple ink that is discharged in defense against predators. ${ }^{1} \mathrm{~A}$ broad range of small pharma- cologically active compounds, some of which originate from ingested Cyanobacteria, have been isolated from different sea hare genera including Aplysia and Dolabella. ${ }^{2}$ In addition, several Aplysia and Dolabella species produce glycoproteins with antitumor and bactericidal activity including the Aplysianins, Dolabellanins, and Cyplasins. ${ }^{3,4}$ The molecular mechanism of the antitumor activity of these factors has so far not been elucidated.

At least three pathways of cell death with distinct phenotypes are known to date; apoptosis, necrosis, and oxidative damage. ${ }^{5}$ Apoptosis, a genetically fixed physiological form of cell death, is accompanied by shrinkage, membrane blebbing, nuclear fragmentation, and final disintegration of the dying cell into so-called apoptotic bodies. ${ }^{6}$ In contrast, necrosis is a pathological process characterized by membrane disruption and cell swelling. The phenotype of cell death induced by reactive oxygen species (ROS) is less well defined; for example, induction of apoptosis and necrosis, ${ }^{7}$ and other forms of cell death, ${ }^{8}$ have been described.

Tumor cells show an increased ROS production compared to normal cells ${ }^{9,10}$ and ROS are thought to play multiple roles in tumor initiation, progression, and maintenance. ${ }^{11}$ ROSinduced DNA damage may promote tumorigenesis. Moreover, cellular stress response kinases are activated by ROS like extracellular signal-regulated kinases (ERKs), c-Jun $\mathrm{N}$-terminal kinases (JNK), and p38. Interestingly, tumor cells sensitive to anticancer therapy show higher levels of ROS and stress responses than drug-resistant tumor cells. ${ }^{12}$ Eucaryotic cells have developed different enzymatic systems to neutralize potential harmful ROS such as superoxide dismutase, catalase, glutathione peroxidases, and thioredoxin peroxidases. Overproduction of thioredoxin peroxidases, also known as peroxiredoxins, ${ }^{13,14}$ is found in many types of cancers. ${ }^{15,16}$

$\mathrm{Bcl}-2$ family proteins are involved in the regulation of apoptosis. They are of major medical importance since overexpression of inhibitory members or mutational inactivation of activating members has been implicated in tumor cell growth and tumor therapy resistance. ${ }^{17}$ However, besides playing an important role in the regulation of apoptosis, they have also been found to regulate apoptosis-independent stress-related forms of cell death. ${ }^{18}$

We have identified and purified a new protein from the ink of Aplysia punctata that causes death of tumor cells but not of peripheral blood mononuclear cells (PBMC) and human umbilical vein endothelial cells (HUVEC). The characteristics of cell death induced by the Aplysia punctata ink toxin (APIT) reflects neither an apoptotic nor a clear necrotic form of cell death but is rather typical of oxidative damage. The mechanism of the cytolytic activity of APIT is the continuous enzymatic production of $\mathrm{H}_{2} \mathrm{O}_{2}$. Furthermore, knockdown of peroxiredoxin I (Prx I) expression by RNA interference (RNAi) demonstrated the specific involvement of Prx I in signaling pathways induced by APIT. 


\section{Results}

\section{Purification of a new compound with tumor lytic activity from $A$. punctata}

The ink of $A$. punctata contains an unknown activity that efficiently kills tumor cells (Figure 1a). Tumor cells exposed to ink exhibited a characteristic phenotype; loss of contact to neighboring cells, appearance of vacuoles in the cytoplasm, and nuclei shrinkage (Figure 1a). In order to purify the tumor lytic factor, ink from $A$. punctata was subjected to ion exchange chromatography (Figure 1b) and subsequent gel filtration chromatography (Figure 1c). Each fraction was tested for toxic activity by measuring the metabolic activity of treated Jurkat cells (Figure 1b,c). Activity correlated with the presence of a protein of approximately $60 \mathrm{kDa}$ (Figure 1d), whereas inactive fractions did not contain a $60 \mathrm{kDa}$ band (not shown). Since Jurkat cells exhibited the same phenotype when either treated with the purified APIT or the crude ink (Figure 1a), we concluded that APIT is the main factor exhibiting cytolytic activity in the ink. The gene of APIT was cloned and sequenced (Genbank accession numbers AY442281, AY442282, AY442283). APIT exhibited significant homology to L-amino-acid oxidases, Aplysianins, and Cyplasins (manuscript in preparation).

\section{APIT-induced cell death is independent of apoptosis}

To further characterize the mode of cell death induced by APIT, metabolic activity, membrane permeabilization, as well as apoptotic features of treated cells were investigated. Metabolic activity of tumor cells was blocked as early as 30 min after exposure to APIT (Figure 2a). Tumor cells took up propidium iodide $(\mathrm{PI}) 2 \mathrm{~h}$ after APIT treatment indicating plasma membrane permeabilization and cell death (Figure 2b). Treated cells exhibited neither sole morphological signs of apoptotic or necrotic cell death (Figure 1a, 2c), as no blebbing or swollen cells were detected when cells were treated with a lethal dose of APIT. Corresponding to the absence of apoptosis, caspases were not activated in treated cells as determined by 2-DE analysis of previously identified caspase substrates like Rho GDI-2 or hnRNPs (not shown). ${ }^{19}$ Consistent with the absence of active caspases, the broadrange caspase inhibitor ZVAD-fmk failed to prevent cell death induced by ink or by purified APIT, but efficiently blocked apoptosis induced by doxorubicin or low $\mathrm{H}_{2} \mathrm{O}_{2}$ concentrations (Figure 2c). As a further hallmark of apoptosis, the fragmentation of DNA was investigated in treated cells. No processing of DNA into oligonucleosomal fragments occurred in treated cells as monitored by gel electrophoresis (Figure 2d). However, treated cells were positive in TUNEL analyses, indicating that APIT induced DNA-strand breaks, probably singlestrand breaks, with high efficiency (Figure 2e). Collectively, these data demonstrate that APIT-induced cell death occurs independent of apoptosis.

\section{Tumor specificity of APIT}

To analyze the specificity of APIT for tumor cells, PBMC from healthy donors and Jurkat cells were incubated with increas- ing amounts of purified APIT and analyzed for PI uptake (Figure 3a). Even at the highest APIT concentrations used in this experiments, only $28 \%$ of the peripheral blood cells took up $\mathrm{PI}$, indicative of membrane disintegration, compared to $80 \%$ of the tumor cells. Determination of the release of cytoplasmic lactate dehydrogenase (LDH) as a further marker of membrane permeabilization strongly confirmed these data (not shown). Beside PBMC, also HUVEC were highly resistant against APIT-induced cell death as shown in Figure $3 \mathrm{~b}$. Even at a APIT concentration of $40 \mathrm{ng} / \mathrm{ml}$, LDH release of HUVEC cells remained below $10 \%$, in contrast to $\mathrm{LDH}$ release of about $70 \%$ of Jurkat cells. Since several tumor cell lines showed a similar sensitivity as the Jurkat cells (Table 1) but normal PBMC and HUVEC were resistant to APIT, our data suggest that the toxic effect induced by APIT is tumor specific.

Antiapoptotic Bcl-2 family proteins are involved in the regulation of apoptotic cell death induced by a wide variety of stimuli. ${ }^{20}$ Since many anticancer drugs kill tumor cells by inducing Bcl-2-dependent apoptotic cell death, overexpression of $\mathrm{Bcl}-2$ family proteins has been recognized as an important aspect of tumor therapy resistance. ${ }^{17}$ In order to test the influence of antiapoptotic $\mathrm{Bcl}-2$ proteins on APITinduced cell death, tumor cell lines overexpressing Bcl-2 or $\mathrm{Bcl}-\mathrm{X}_{\mathrm{L}}$, and the respective control cell lines were analyzed. In contrast to control cells, doxorubicin-induced reduction of metabolic activity was inhibited in the $\mathrm{Bcl}-2$ - or $\mathrm{Bcl}-\mathrm{X}_{\mathrm{L}}$ overexpressing cells demonstrating the functional expression of $\mathrm{Bcl}-2$ and $\mathrm{Bcl}-\mathrm{X}_{\mathrm{L}}$ (Table 1). Interestingly, tumor cells overexpressing $\mathrm{Bcl}-2$ or $\mathrm{Bcl}-\mathrm{X}_{\mathrm{L}}$ exhibited the same sensitivity for APIT as the corresponding control lines (Table 1). These results suggested that APIT-induced cell death does not interfere with $\mathrm{Bcl}-2$ - or $\mathrm{Bcl}-\mathrm{X}_{\mathrm{L}}$-sensitive apoptosis pathways.

\section{APIT kills tumor cells by $\mathrm{H}_{2} \mathrm{O}_{2}$ production}

In order to investigate the mechanism by which APIT induces cell death, proteome analyses of treated and untreated tumor cells were performed. Interestingly, the most prominent change observed was the shift of a $22 \mathrm{kDa}$ protein spot from pl 8.3 to 7.7 (Figure 4a). These protein spots were identified as Prx I by peptide mass fingerprinting.

Prx $\mathrm{I}$ is located in the cytoplasm and is involved in the detoxification of $\mathrm{H}_{2} \mathrm{O}_{2}$ and other peroxides. ${ }^{21-24}$ Cells were treated with APIT and the $\mathrm{H}_{2} \mathrm{O}_{2}$-degrading enzyme catalase to investigate whether $\mathrm{H}_{2} \mathrm{O}_{2}$ is involved in APIT-induced toxicity. Catalase completely prevented cytolysis (Figure 4b) and the rapid loss of metabolic activity (Figure 4c). As expected, catalase was ineffective in blocking CD95(Fas/ Apo-1)-induced cell death in the same assay (Figure 4c). In the presence of catalase, APIT failed to induce morphological changes of tumor cells as judged by microscopy (Figure 4d). Catalase treatment also completely prevented the permeabilization of PBMC, suggesting that the minor toxic effect on normal cells also depends on the enzymatic activity of APIT (data not shown). The highly efficient inhibition of catalase in particular suggested that no other substance than $\mathrm{H}_{2} \mathrm{O}_{2}$ elicits the toxic effect observed in APIT-treated samples. Moreover, catalase also inhibited tumor cell lysis induced by ink (Figure $4 b, d)$, and high concentrations of $\mathrm{H}_{2} \mathrm{O}_{2}$ induced the 


\section{a}
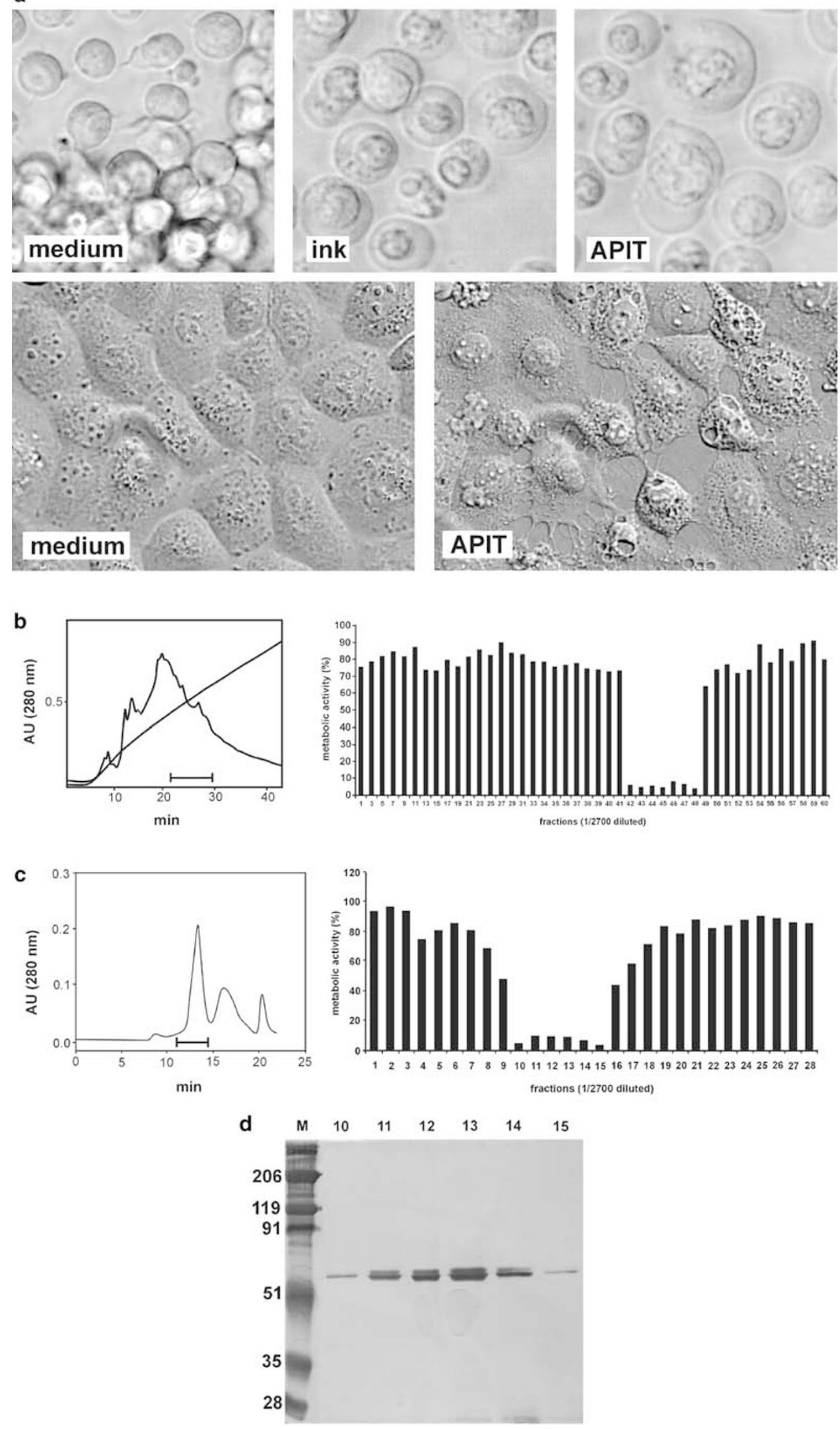
phenotype typical for APIT-treated cells (Figure 4d), indicating that the cytotoxic effect of ink is caused by $\mathrm{H}_{2} \mathrm{O}_{2}$ production. Furthermore, proteome analyses revealed the same changes in the protein pattern in $\mathrm{H}_{2} \mathrm{O}_{2}$-treated and APIT-treated cells (data not shown).

The data obtained so far did not allow us to determine if APIT induces peroxide production in treated cells or if it contains an enzymatic activity that produces peroxide. To distinguish between these possibilities, $\mathrm{H}_{2} \mathrm{O}_{2}$ was measured using an enzymatic assay based on the conversion of ABTS 2,2-azino-bis (3-ethylbenzthiazoline-6-sulfonic acid) by horseradish peroxidase in samples of APIT-treated cells, and also in medium containing APIT in the absence of cells. As shown in Figure $4 \mathrm{e}, \mathrm{H}_{2} \mathrm{O}_{2}$ was produced by APIT in cell culture medium even in the absence of cells. Under these conditions, $\mathrm{H}_{2} \mathrm{O}_{2}$ was produced at $300 \mu \mathrm{M}$ after $90 \mathrm{~min}$ (Figure $4 \mathrm{e}$ ), which would be sufficient to induce cell death (data not shown). $\mathrm{H}_{2} \mathrm{O}_{2}$ concentrations measured in the presence of cells were generally lower due to $\mathrm{H}_{2} \mathrm{O}_{2}$ consumption by the cells. These data clearly demonstrated that the cytotoxic activity is dependent on the $\mathrm{H}_{2} \mathrm{O}_{2}$-producing enzymatic activity of APIT.

\section{Knockdown of Prx I sensitized cells for APIT-induced cell death}

Prx I exhibited the most significant modification observed in 2DE protein patterns of APIT-treated cells in comparison to untreated Jurkat cells. Since Prx $I$ is involved in ROS detoxification, ${ }^{21-24}$ we asked whether Prx I was involved in a signaling pathway induced by APIT. If Prx I was involved in the detoxification of $\mathrm{H}_{2} \mathrm{O}_{2}$ produced by APIT, we expected to observe a sensitization in cells in which Prx I expression is decreased. To measure sensitization, conditions were chosen under which the reduction of metabolic activity of treated cells was $50 \%$ or less of the untreated cells. siRNAs were transfected into HeLa cells and after $72 \mathrm{~h}$ cells were treated with APIT for $6 \mathrm{~h}$ and the metabolic activity was determined. In parallel, cells were harvested for quantitative analysis of the respective mRNAs by realtime PCR (Figure $5 \mathrm{a}$ ). The mRNA of Prx I was reduced by more than $90 \%$ compared to the mRNA level of GAPDH. Interestingly, this reduction of Prx I expression significantly sensitized the cells for killing by APIT, whereas control siRNA directed against Luciferase and Lamin $\mathrm{A} / \mathrm{C}$ had no effect (Figure $5 \mathrm{~b}$ ). Thus, our data show that Prx I is involved in a protective pathway against APIT toxicity in tumor cells.

\section{Discussion}

The overall aim in tumor therapy is the selective eradication of transformed cells without harming healthy cells. Several glycoproteins isolated from sea hares have attracted attention because of their reported antitumor activity. ${ }^{3}$ The underlying mechanism for such activity has, however, not been elucidated. Here we demonstrate that APIT, a protein of the ink of $A$. punctata, lyse tumor cells by the production of $\mathrm{H}_{2} \mathrm{O}_{2}$. This basic mechanism of APITs tumorizidal activity was confirmed by our biochemical and molecular analyses which revealed that APIT is an L-amino-acid oxidase producing $\mathrm{H}_{2} \mathrm{O}_{2}$ via oxidation of amino acids (manuscript in preparation). Since the amino-acid sequence of APIT is homologous to Aplysianins and Cyplasins, we suggest that these toxins are $\mathrm{H}_{2} \mathrm{O}_{2}$-producing amino-acid oxidases. Moreover, we present evidence that $\operatorname{Prx} \mathrm{I}$ is involved in the detoxification of $\mathrm{H}_{2} \mathrm{O}_{2}$ in tumor cells.

The major modification identified in 2-DE patterns of cells treated with APIT was a significant shift in the pl of Prx I. Prx I belongs to a class of peroxidases involved in the detoxification of $\mathrm{H}_{2} \mathrm{O}_{2}$ and other peroxides. ${ }^{24}$ Therefore, we concluded that the generation of peroxides is the mechanism by which APIT induced the lysis of tumor cells. Thus, the modification of Prx I could be used as a marker for APITs antitumor activity. Since the same modification of Prx I was detected in cells treated with $\mathrm{H}_{2} \mathrm{O}_{2}$, antitumor activities of APIT other than production of $\mathrm{H}_{2} \mathrm{O}_{2}$ are very unlikely. This conclusion was confirmed by the inhibition of APIT-induced tumor cell death by catalase, an $\mathrm{H}_{2} \mathrm{O}_{2}$ hydrolyzing enzyme. Catalase also prevented tumor cell death induced by crude ink, further demonstrating that no other activity than the production of $\mathrm{H}_{2} \mathrm{O}_{2}$ is responsible for the ink-mediated killing of tumor cells.

Tumor cells treated with APIT displayed an unusual morphology which was neither typical for apoptosis or for necrosis. Shrunken nuclei and lack of cell swelling are typical characteristics of apoptosis, and early membrane permeabilization of necrosis. Interestingly, APIT induced no oligosomal DNA fragmentation but probably single-strand DNA breaks detected by TUNEL assay. High $\mathrm{H}_{2} \mathrm{O}_{2}$ concentrations are able to induce single-strand breaks by activating endonuclease. ${ }^{25}$ The phenotype induced by APIT could be reproduced by treatment of the cells with $\mathrm{H}_{2} \mathrm{O}_{2}$ at concentrations above $200 \mu \mathrm{M}$ (Figure 4d). Interestingly, $\mathrm{H}_{2} \mathrm{O}_{2}$ concentrations $<100 \mu \mathrm{M}$ induced typical apoptosis in Jurkat cells (Figure 2c). These observations are confirmed by recent publications showing that $\mathrm{H}_{2} \mathrm{O}_{2}$ may either induce apoptosis or a further noncharacterized form of cell death depending on the amount of $\mathrm{H}_{2} \mathrm{O}_{2} \cdot{ }^{26}$ The dose dependency of the phenotype induced by $\mathrm{H}_{2} \mathrm{O}_{2}$ treatment is also in agreement with the notion that many toxic insults may either induce apoptosis or necrosis, dependent on the magnitude rather than on the nature of the insult. ${ }^{7}$ Interestingly, a phenotype very similar to that induced by APIT has been described as a result of treating cells with the electron transport chain inhibitor antimycin A. ${ }^{8}$ Cells die by apoptosis at low doses of

Figure 1 (a) Phenotype of APIT-induced cell death. Jurkat T cells (upper panel) or HeLa cells (lower panel) were cultured for $7 \mathrm{~h}$ in medium, ink or APIT as indicated and bright field and phase contrast images were recorded, respectively. (b) Anion exchange chromatography of ink and activity assay of single fractions. Proteins were eluted by a linear gradient from 0 to $800 \mathrm{mM} \mathrm{NaCl}$. Absorption was measured at $280 \mathrm{~nm}$ (AU: absorption unit). Horizontal bar indicates active fractions, which were determined as shown in the adjacent diagram: Jurkat cells were treated with diluted fractions (1/2.700) and their metabolic activity was recorded as percent of medium control. (c) Active fractions of (b) were subjected to gel filtration chromatography and active fractions were determined as described under (b). (d) Silver-stained SDSPAGE of the active fractions obtained by gel chromatography. Both protein bands at $60 \mathrm{kDa}$ consist of the same amino-acid sequence as indicated by identical peptide mass fingerprints 

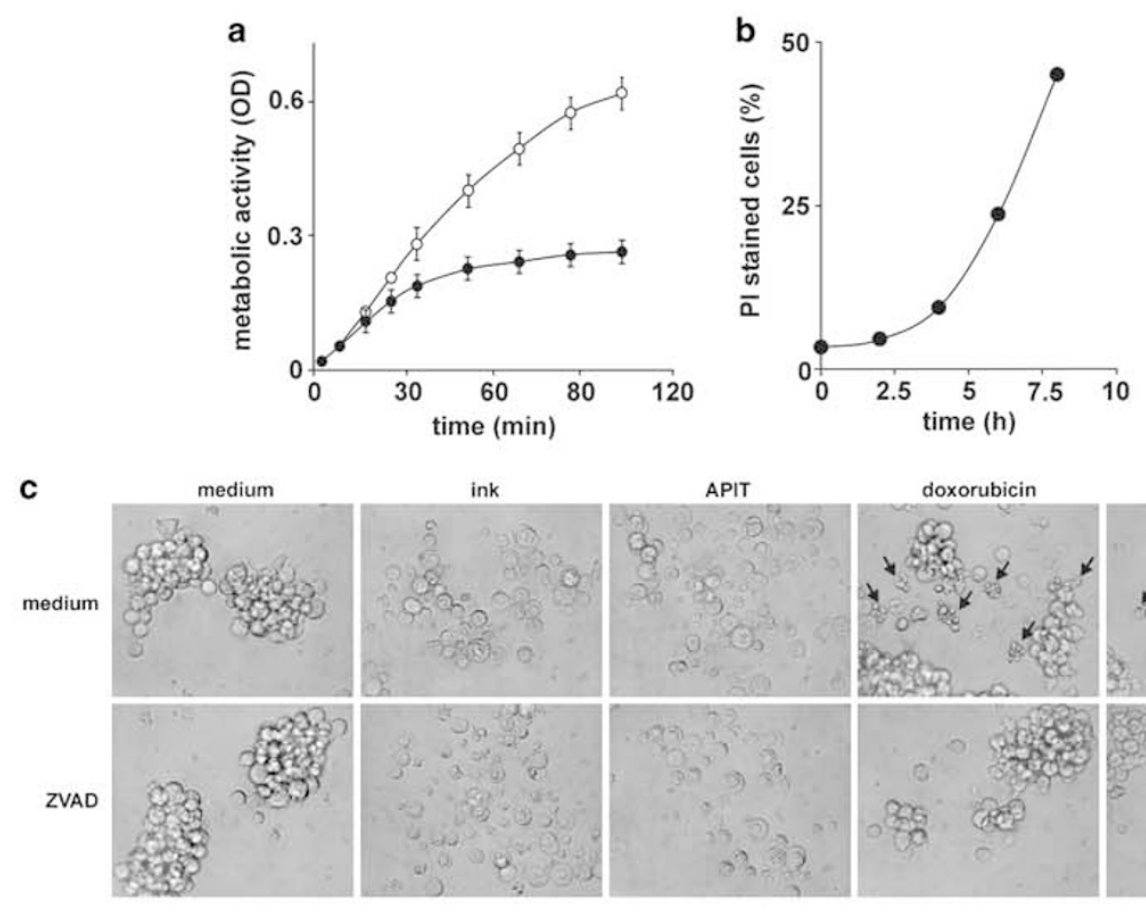

APIT

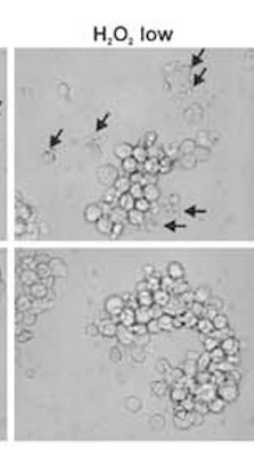

d
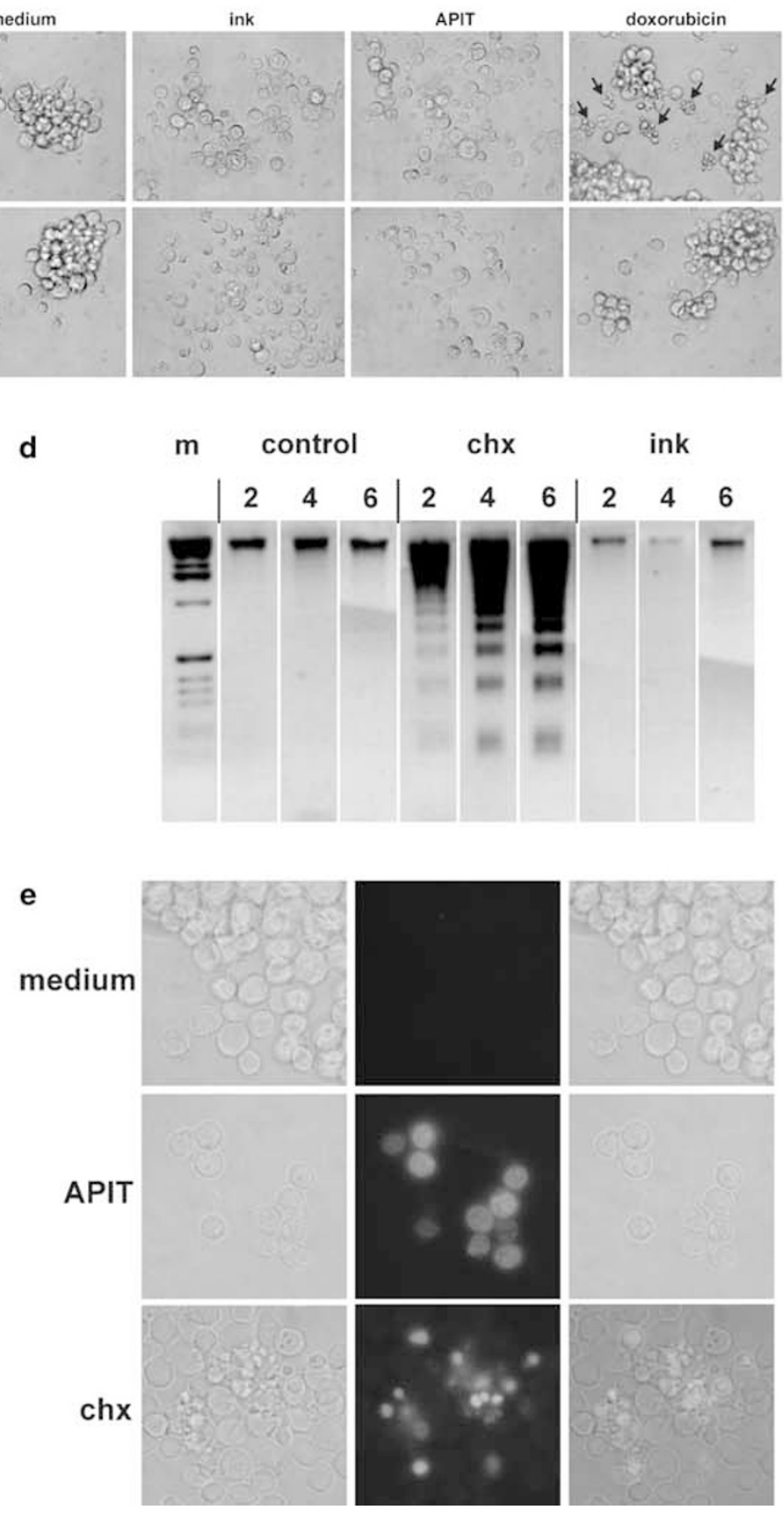

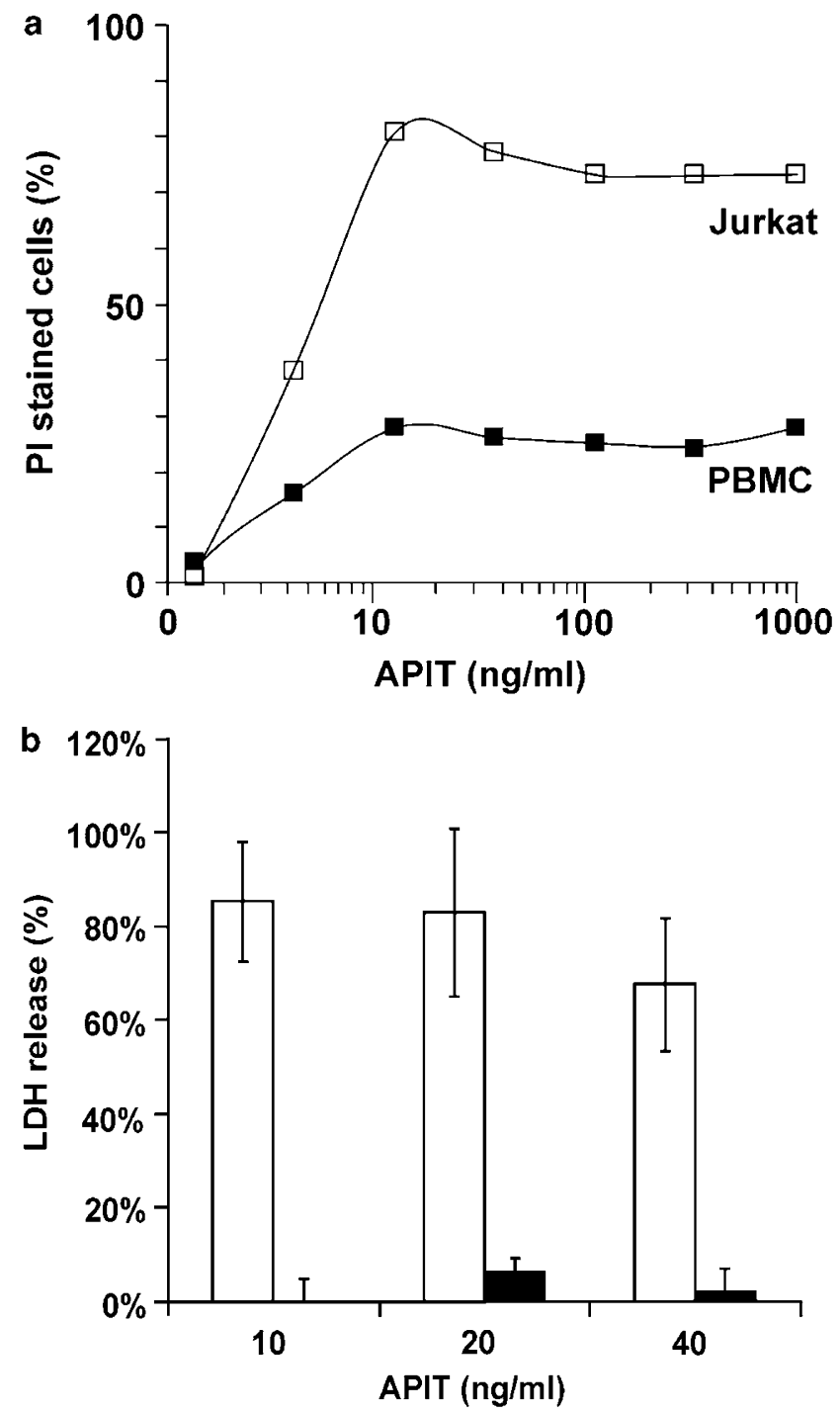

Figure 3 (a) Sensitivity of tumor cells and PBMC to APIT-induced cell death Jurkat cells and PBMC from healthy donors were cultured for $14 \mathrm{~h}$ in the presence of increasing amounts of APIT. Cell death was measured as PI uptake. (b) HUVEC cells are resistant to APIT-induced cells death. HUVEC (black bars) and Jurkat cells (white bars) were incubated over night with increasing amounts of APIT. Subsequently, LDH release in the culture supernatant was measure photometrically. The results of two independent experiments \pm the S.D. are shown

antimycin A, while at higher doses features of apoptotic and necrotic cell death can be detected. ${ }^{8}$ Interestingly, antimycin A induces the rise of intracellular $\mathrm{H}_{2} \mathrm{O}_{2} \cdot{ }^{27}$ Both APIT and antimycin $A$, although by different mechanisms, might thus
Table 1 APIT kills apoptosis-resistant tumor cell lines

\begin{tabular}{lcc}
\hline Tumor cell line & IC $_{\mathbf{5 0}}$ (APIT, $\left.\mathbf{n g} / \mathbf{m l}\right)$ & $\begin{array}{c}\text { Metabolic activity } \\
\text { after doxorubicin } \\
\text { treatment (\%) }\end{array}$ \\
\hline Jurkat neo & $3.2 \pm 0.7$ & $32.5 \pm 5.5$ \\
Jurkat Bcl-2 & $2.7 \pm 0.6$ & $80.0 \pm 4.0$ \\
CEM neo & $5.6 \pm 0.7$ & $27.0 \pm 7.0$ \\
CEM BCl-X & $4.1 \pm 0.1$ & $75.0 \pm 1.0$ \\
K562 & $4.3 \pm 0.2$ & $80.5 \pm 8.5$ \\
\hline
\end{tabular}

The $\mathrm{IC}_{50}$ values reflect the APIT concentration at which the metabolic activity of the tumor cells is decreased to $50 \%$ compared to the medium control. Apoptosis resistance of the $\mathrm{Bcl}-2$ and $\mathrm{Bcl}-\mathrm{X}_{\mathrm{L}}$ transfected and of the naturally resistant K562 cell lines was confirmed via increased metabolic activity after doxorubicin treatment $(10 \mu \mathrm{M})$ in comparison to mock-transfected cell lines. The results of three independent experiments \pm the S.D. are shown.

lead to the accumulation of the same effector molecule, $\mathrm{H}_{2} \mathrm{O}_{2}$, which at a certain level induces this special form of cell death.

$\mathrm{H}_{2} \mathrm{O}_{2}$ and the resulting free radicals are involved in a plethora of physiological and pathological signaling pathways. ${ }^{28}$ The mechanism by which $\mathrm{H}_{2} \mathrm{O}_{2}$ itself interacts with protein function depends on its oxidative potential for thiol proteins. Such a group of target proteins influenced by $\mathrm{H}_{2} \mathrm{O}_{2}$ might be the caspases, a family of cysteine proteases that play an important role in apoptotic signaling. ${ }^{29}$ Interestingly, $\mathrm{H}_{2} \mathrm{O}_{2}$ has been shown to have a dual function on caspases; addition of $\mathrm{H}_{2} \mathrm{O}_{2}$ to cells at low concentrations $(50 \mu \mathrm{M})$ activates caspases and induces apoptosis. At higher concentrations $(>200 \mu \mathrm{M}), \mathrm{H}_{2} \mathrm{O}_{2}$ inhibits the activation of caspases and rather induces necrosis. ${ }^{30} \mathrm{H}_{2} \mathrm{O}_{2}$ also inhibits the activation of recombinant caspases suggesting that the caspase inhibitory effect is dependent on direct interference with caspase activity. ${ }^{31}$ Therefore, it might well be that APIT produces levels of $\mathrm{H}_{2} \mathrm{O}_{2}$ that damage the cell but prevent apoptosis by blocking caspase function.

Knockdown of Prx I by RNAi rendered the cells hypersensitive for APIT, suggesting that Prx I is part of an $\mathrm{H}_{2} \mathrm{O}_{2}$ detoxifying pathway. Peroxiredoxins comprise a class of highly conserved oxidases. ${ }^{32}$ In mammals, six different isoforms are known. ${ }^{13,14}$ Peroxiredoxins catalyze the reduction of peroxides by using reducing equivalents that are provided by thioredoxin or glutathione. During catalysis, Prx I is inactivated by oxidation of the active site cysteine to cysteine sulfinic acid, ${ }^{33}$ a modification which is reversible upon removal of $\mathrm{H}_{2} \mathrm{O}_{2}$. ${ }^{34}$ The modification of $\mathrm{Prx} \mathrm{I}$ that we observed in 2-DE gel analysis of APIT-treated cells resembles

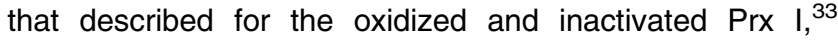
indicating that APIT inactivates this detoxification system. Previously, overexpression of both Prx I and Prx II has been shown to render cells resistant to $\mathrm{H}_{2} \mathrm{O}_{2}$-induced

Figure 2 (a) Cell death induced by APIT measured by the loss of metabolic activity. APIT and the tetrazolium-salt WST-1 were added simultaneously to Jurkat cells and the turnover of WST-1 was measured photometrically. White circles: medium control; black circles: APIT-treated samples; mean absorbance of eight replicates \pm S.D. (b) Jurkat cells were treated with ink and PI uptake was measured. (c) Influence of the caspase inhibitor ZVAD-fmk on APIT-induced cell death or apoptosis. Jurkat cells were either treated for $6 \mathrm{~h}$ with ink or APIT or with the apoptosis inducers doxorubicin or $\mathrm{H}_{2} \mathrm{O}_{2}$ at $62,5 \mu \mathrm{M}\left(\mathrm{H}_{2} \mathrm{O}_{2}\right.$ low), as indicated in the absence (upper panel) or presence of ZVAD-fmk (lower panel). Arrowheads point to apoptotic cells. Note that apoptosis but not the APIT-induced cell death is blocked by zVADfmk. (d) Lack of apoptotic DNA fragmentation in ink-treated cells. Jurkat cells were incubated in medium (control) or treated with cycloheximide (chx) or ink (ink) for 2, 4, and $6 \mathrm{~h}$. Isolated DNA was visualized on a 1,6\% agarose gel by ethidium bromide staining. (e) DNA-strand breaks in APIT- and apopotsis-induced cell death. Jurkat cells were either left untreated (upper panel), treated with APIT (middle panel) or cycloheximide (chx, lower panel); $m=$ marker. Apoptotic and APIT-treated cells were both TUNEL positive, but only the nuclei of apoptotic cells fragmented into apoptotic bodies 

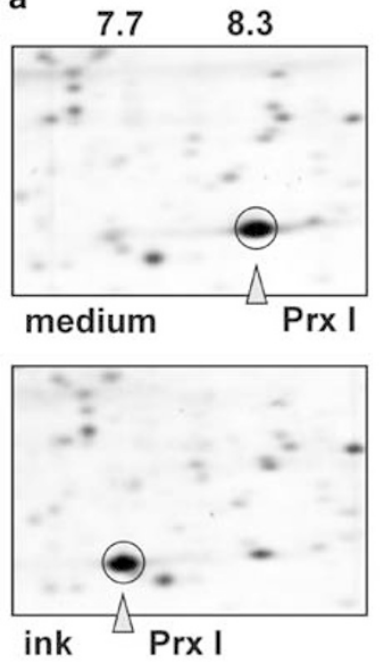

d
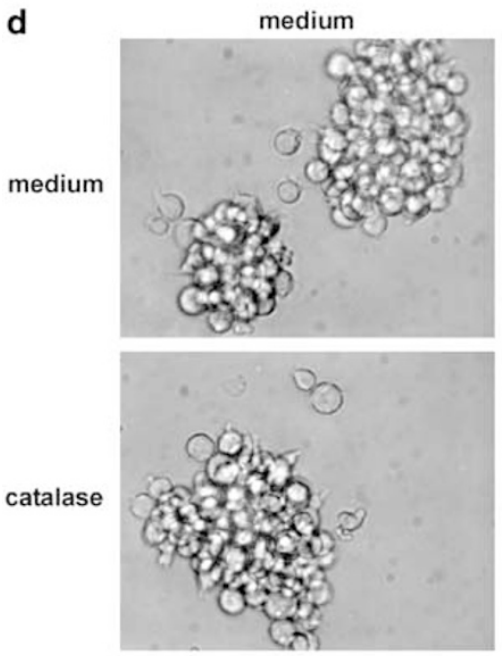

22.1 b

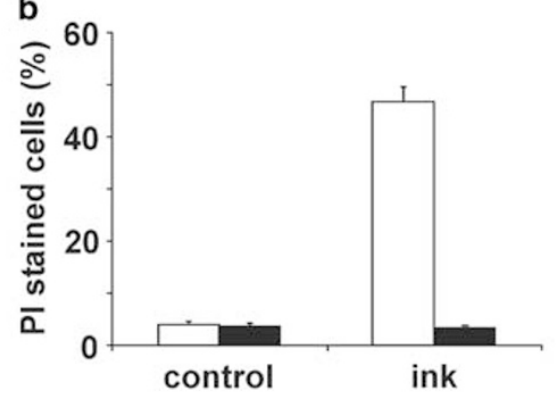

c

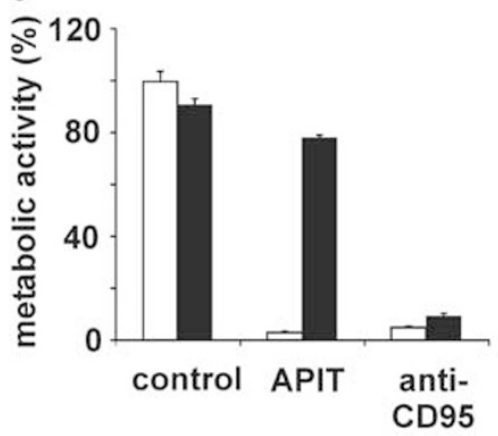

ink
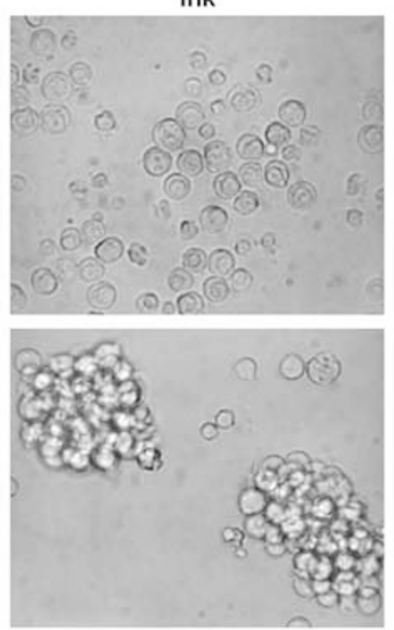

APIT
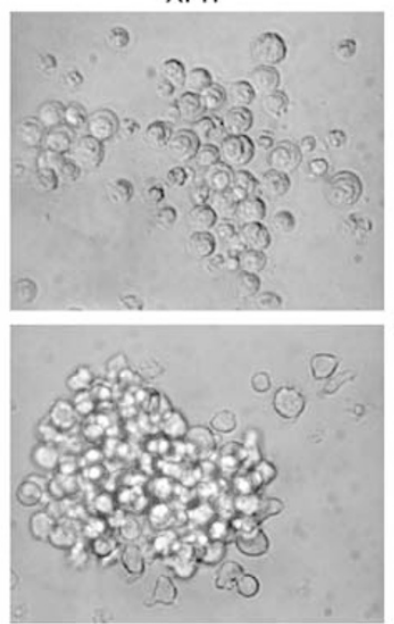
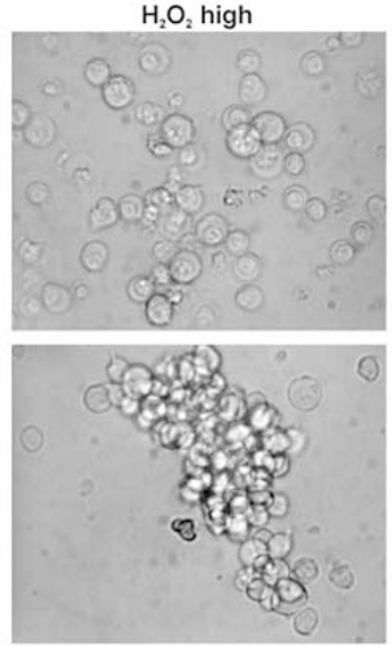

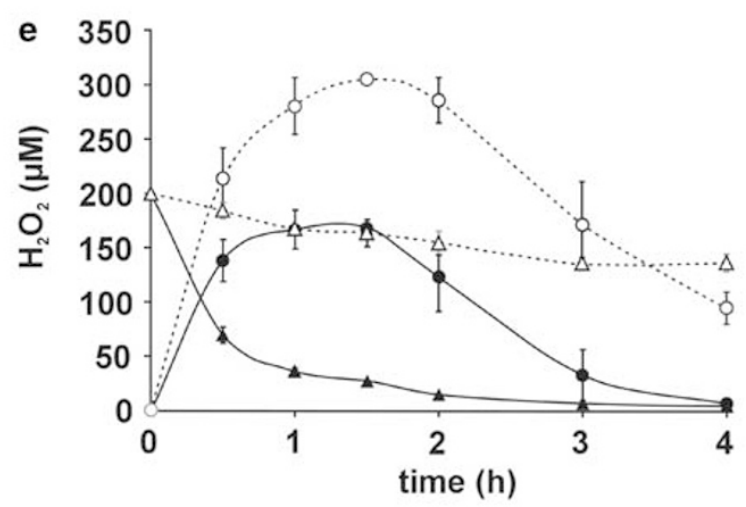

Figure 4 (a) Proteome analysis of Jurkat cells cultured for $8 \mathrm{~h}$ in the presence (ink) or absence (medium) of ink. The pl of Prx l in control (8.3) and ink-treated cells (7.7), as well as the mass of $22.1 \mathrm{kDa}$ is indicated. (b) Catalase inhibits ink-induced cell death. Jurkat T cells were incubated for $8 \mathrm{~h}$ with ink in the presence (black bars) or absence (white bars) of catalase. Cytotoxicity was measured as PI uptake (mean of triplicates \pm S.D.). (c) Catalase protects from APIT-induced loss of metabolic activity. Metabolic activity of Jurkat cells was measured after incubation with APIT or anti-CD95 for $3 \mathrm{~h}$ in the presence (black bars) or absence (white bars) of catalase (mean of five replicates \pm S.D.). (d) Phenotype of ink and APIT-induced cell death is mediated by $\mathrm{H}_{2} \mathrm{O}_{2}$. Jurkat cells were cultured for $7 \mathrm{~h}$ in medium, ink, $\mathrm{APIT}$, or $\mathrm{H}_{2} \mathrm{O}_{2}(500 \mu \mathrm{M}$; high) in the absence (upper panel) or presence of catalase (lower panel). Cell morphology was analyzed by bright field microscopy. (e) APIT generates $\mathrm{H}_{2} \mathrm{O}_{2}$ in cell culture medium. Jurkat cell suspension (filled) or medium alone (open) was incubated with APIT (circles) or $200 \mu \mathrm{M} \mathrm{H}_{2} \mathrm{O}_{2}$ (triangles). $\mathrm{H}_{2} \mathrm{O}_{2}$ in the supernatants was measured quantitatively at the indicated time points (means of three independent experiments \pm S.D.) 
apoptosis. ${ }^{24,35,36}$ Our finding of a specific involvement of $\operatorname{Prx} I$ in a pathway counteracting the toxic activity of $\mathrm{H}_{2} \mathrm{O}_{2}$ is, to our best knowledge, the first report on a specific function of Prx I demonstrated in a loss of function experiment.

Why do amino-acid oxidases of Aplysia exhibit tumor specific toxicity? From many studies, it is known that tumor cells have an increased rate of metabolism compared to normal cells. A result of this high metabolic rate is a high concentration of ROS that originate from oxidative phosphorylation reactions by the electron transport chain of the mitochondria. As a consequence, ROS detoxification reactions are increased in tumor cells, and interference with detoxification has a selective toxic effect on tumor cells but not on normal cells. ${ }^{11}$ Likewise, increasing the concentration of ROS at a certain level might overcome the detoxification reactions and kill the tumor cell. The same level of extra ROS produced by exogenous APIT might not affect normal cells because of their higher tolerance for additional ROS.

In summary, we have shown that the tumor lytic activity of the ink from $A$. punctata is mediated by the ink toxin APIT via the enzymatic production of $\mathrm{H}_{2} \mathrm{O}_{2}$. APIT-induced tumor cell death is apoptosis independent and characterized by early membrane permeabilization. We identified the modification of Prx I as an important step in the APIT-mediated death pathway, which according to literature reflects an oxidation and inactivation of this detoxification system. The fact that the knockdown of Prx I expression by RNAi increased the sensitivity of tumor cells for the cytolytic activity of APIT underlines the impact of this event. In addition, APIT might lead to inactivation of caspases and other molecules necessary for the integrity and metabolism of the cells. The knowledge about the mode of action of this interesting class of antitumor enzymes may allow for the design of novel anticancer therapies.

\section{Materials and Methods}

\section{Animals}

A punctata were gained from the Station Biologique de Roscoff, France. Crude ink was prepared by gentle squeezing the sea hares in sterile seawater. Insoluble particles were removed by ultracentrifugation $\left(82000 \mathrm{~g}, 30 \mathrm{~min}, 4^{\circ} \mathrm{C}\right)$ and supernatants were stored at $-70^{\circ} \mathrm{C}$.

\section{Cells, media, and reagents}

Jurkat, HeLa, and K562 cells were obtained from ATCC. HUVEC were prepared as described before. ${ }^{37}$ Mock- and Bcl-2-transfected Jurkat cells (Jurkat neo, Jurkat Bcl-2) were a kind gift of Dr. K Tomaselli (Idun Pharmaceuticals, La Jolla, USA), mock- and Bcl- $X_{L}$-transfected CEM cells (CEM neo, CEM BCL- $X_{L}$ ) were kindly provided by Dr. M Peter (University of Chicago, USA). Cells were cultured in RPMI medium containing $10 \%$ FCS (Invitrogen), $100 \mathrm{U} / \mathrm{ml}$ penicillin, $100 \mu \mathrm{g} / \mathrm{ml}$ streptomycin. PBMCs were isolated from the heparin-treated blood of healthy donors by density centrifugation. In brief, blood was diluted $1: 2$ with PBS w/o $\mathrm{Ca}^{2+}$ and $\mathrm{Mg}^{2+}$, overlaid on Ficoll/lsopaque $(P=1.077 \mathrm{~g} / \mathrm{ml}$, Seromed $)$ and centrifuged at $600 \times g$ and $20^{\circ} \mathrm{C}$ for $25 \mathrm{~min}$. The mononuclear cells of the interphase were harvested and washed three times. In addition, the following reagents were used: horseradish peroxidase and catalase from Roche; ABTS 2,2-Azino-bis (3-ethylbenzthiazoline-6-sulfonic acid),
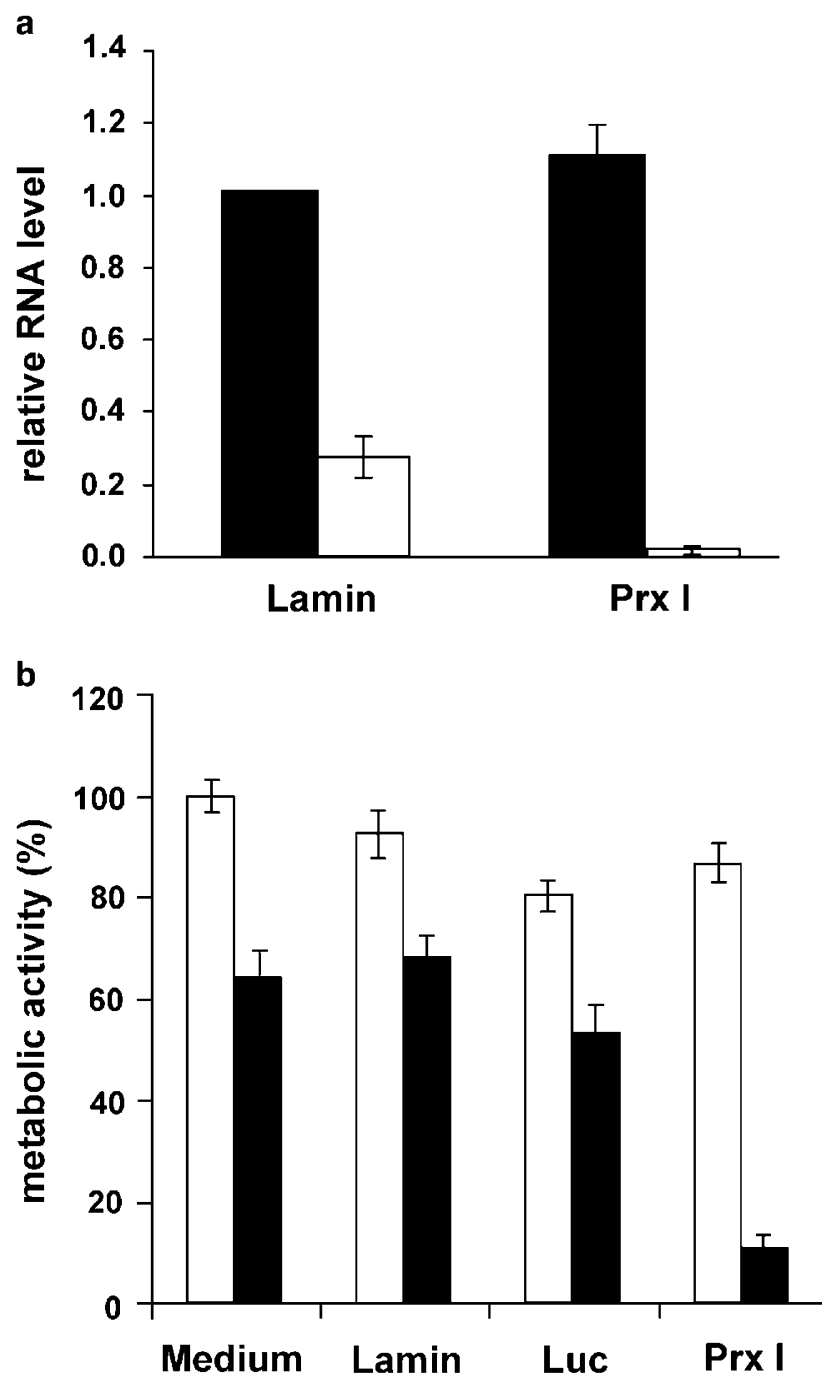

Figure 5 (a) Quantification of the mRNAs of Lamin A/C and Prx I after transfection of specific siRNA (open bars) and control Luciferase siRNA (black bars) with quantitative realtime PCR. The relative mRNAs levels compared to the mRNA of GAPDH measured in the same RNA preparation are shown. (b) Sensitization of Jurkat cells by knockdown of Prx I. Specific siRNAs directed against the mRNA of Luciferase (Luc, transfection control), Lamin A/C (control knock down), and Prx I were transfected in HeLa cells and the metabolic activity of transfectants treated in the presence (black bars) or absence of APIT (open bars) was measured. Note that the knockdown of Prx I but not of the other genes sensitized cells for the cytotoxic activity of APIT

doxorubicin, and $\mathrm{H}_{2} \mathrm{O}_{2}$ from Sigma; anti-CD95 antibody clone $\mathrm{CH} 11$ from Immunotech, $\mathrm{N}$-benzyloxycarbonyl-Val-Ala-Asp(Ome)-fluoromethylketone (zVAD-fmk) from Bachem.

\section{Purification of APIT}

Crude ink was filtered and concentrated using Ultrafree-15 Units (exclusion weight $30 \mathrm{kDa}$ ) followed by three washing steps with $20 \mathrm{mM}$ Tris $\mathrm{HCl}(\mathrm{pH}$ 8.2). The concentrate (20-60-fold) was applied to a Source Q15 anion exchange column ( $\varnothing 10 \mathrm{~mm}$, length $40 \mathrm{~mm}$ ) equilibrated with $20 \mathrm{mM}$ Tris HCl, $\mathrm{pH}$ 8.2. Proteins were eluted using a linear gradient from 0 to $800 \mathrm{mM} \mathrm{NaCl}$. The fractions containing cytotoxic activity were pooled, concentrated and loaded onto a Superose 12 HR 10/30 column 
(Pharmacia). Proteins were eluted with $100 \mathrm{mM}$ potassium phosphate buffer ( $\mathrm{pH} \mathrm{7.2)} \mathrm{at} \mathrm{a} \mathrm{flow} \mathrm{rate} \mathrm{of} 0.4 \mathrm{ml} / \mathrm{min}$. The purity of the fractions was determined by SDS-PAGE and silver staining.

\section{2-DE}

Jurkat cells were treated with or without ink for $8 \mathrm{~h}$ and analyzed by 2-DE as described. ${ }^{38}$ Prx I protein was identified by peptide mass fingerprinting analysis after trypsin digestion using the MS-Fit software (http:// prospector.ucsf.edu/ucsfhtml3.2/msfit.htm) as previously described. ${ }^{39}$

\section{Vitality, toxicity, and apoptosis assays}

Jurkat cells suspended at 50000 cells in $100 \mu$ l cell culture medium in 96well plates were treated with ink or APIT. Cell vitality was determined as metabolic activity by the turnover of WST-1 (Roche), a substrate of the mitochondrial dehydrogenase, to red formazan. Absorbance of the cell suspension was measured photometrically at $450 \mathrm{~nm}$ ( $690 \mathrm{~nm}$ reference). Toxicity was determined by quantifying PI ( $1 \mu \mathrm{g} / \mathrm{ml}$ in PBS) uptake by flow cytometry. Cytolytic activity was determined furthermore via the release of cytoplasmic LDH in the supernatant. Release of LDH is found only upon membrane permeabilization by APIT. After APIT treatment, half of the culture supernatants $(50 \mu \mathrm{l})$ were transferred in fresh wells and mixed with $50 \mu \mathrm{l}$ reagent of Cytotoxicity Detection Kit-LDH, according to the manufacturer's instruction (Roche 1644793). LDH release was measured photometrically at $490 \mathrm{~nm}(690 \mathrm{~nm}$ reference) and calculated as the ratio of LDH activity of APIT-treated cells relative to the LDH activity of Triton X100 lysed cells. Fragmented DNA of apoptotic cells was analyzed according to Herrmann et al. ${ }^{40}$ For detection of DNA-strand breaks, cells were treated for $4 \mathrm{~h}$ with APIT, cycloheximide (chx), or medium alone. Subsequently, the 'DeadEnd ${ }^{\mathrm{TM}}$ Fluorimetric TUNEL-Assay' was used according to the manufacturer's instruction (Promega, Technical bulletin No. 235). Catalase was prepared according to Dahlgren and Karlsson ${ }^{41}$ and used at a concentration of $2000 \mathrm{U} / \mathrm{ml}$. Generally, ink was diluted 1/200 and APIT was used at a concentration of 10 or $40 \mathrm{ng} / \mathrm{ml}$ for the treatment of Jurkat or HeLa cells, respectively. The working concentrations of chx was $10 \mu \mathrm{M}$, of zVAD-fmk $50 \mu \mathrm{M}$, and of doxorubicin $10 \mu \mathrm{M}$.

\section{Enzymatic assays}

The production of $\mathrm{H}_{2} \mathrm{O}_{2}$ by APIT was determined via its turnover by horseradish peroxidase. Native ink or APIT were incubated with L-lysine $(1 \mathrm{mM})$ in $100 \mu$ l of $100 \mathrm{mM}$ potassium phosphate buffer, $\mathrm{pH} 7.2$ for $10 \mathrm{~min}$ at $25^{\circ} \mathrm{C}$. The reaction was stopped by adding $1 \mu \mathrm{l}$ of $10 \mathrm{M}$ phosphoric acid. To $25 \mu$ lof this solution $1 \mathrm{mM}$ ABTS (2,2-Azino-bis (3-ethylbenzthiazoline6 -sulfonic acid) and $1 \mathrm{U}$ horseradish peroxidase was added in $225 \mu \mathrm{l}$ of $100 \mathrm{mM}$ potassium phosphate buffer, $\mathrm{pH}$ 5.0. Absorption was measured photometrically at $405 \mathrm{~nm}$ (reference $690 \mathrm{~nm}$ ). The $\mathrm{H}_{2} \mathrm{O}_{2}$ concentrations in cell cultures were determined by removing $100 \mu \mathrm{l}$ aliquots of the supernatant at the indicated time points and treatment with $40 \mu \mathrm{l}$ of $20 \mathrm{mM} \mathrm{N}$-ethylmaleimide in $200 \mathrm{mM}$ sodium acetate, $\mathrm{pH} 5.5$ for $10 \mathrm{~min}$ at room temperature to block interfering thiols. Horseradish peroxidase reaction of the supernatant and $\mathrm{H}_{2} \mathrm{O}_{2}$ standards was performed as described above.

\section{Validation of RNAi by realtime PCR}

A total of $20000 \mathrm{HeLa}$ cells/well were seeded in a 96-well plate one day prior to transfection. Transfection was performed with $0.25 \mu \mathrm{g}$ siRNA directed against Prx I (AAGGCUGAUGAAGGCAUCUCGDTdT), Lamin A/
C (CUGGACUUCCAGAAGAACAdTdT), and Luciferase (CUUACGCUGAGUACUUCGAdTdT) as control and $2 \mu$ transmessenger per well using the transmessenger transfection kit (Qiagen, Hilden, Germany), according to manufacturer's instructions. For the APIT treatment, transfections were conducted in triplicates. At $24 \mathrm{~h}$ after transfection, cells were splitted and grown for additional $48 \mathrm{~h}$ before fresh medium with or without APIT was added for $6 \mathrm{~h}$. Assay conditions, which led to a $50-70 \%$ reduction of the metabolic activity of treated cells, were chosen for RNAi experiments. In parallel, RNA from about 50000 cells was isolated using the RNeasy ${ }^{\circledR} 96$ BioRobot ${ }^{\circledR} 8000$ system (Qiagen) $48 \mathrm{~h}$ after transfection. The relative amount of mRNA was determined by realtime PCR using Quantitect ${ }^{\mathrm{TM}}$ SYBR $^{\circledR}$ Green RT-PCR Kit from Qiagen following manufacturer's instructions. The expression level of Prx mRNA was normalized against the internal standard GAPDH. The following primers were used: Prx I 5': CTGTTATGCCAGATGGTCAG, Prx I $3^{\prime}$ : GATACCAAAGGAATGTTCATG, Lamin A/C 5': CAAGAAGGAGGGTGACCTGA, Lamin A/C 3': GCATCTCATCCTGAAGTTGCTT, GAPDH 5': GGTATCGTGGAAGGACTCATGAC, GAPDH 3': ATGCCAGTGAGCTTCCCGTTCAG.

\section{Acknowledgements}

We thank the Station Biologique de Roscoff (France) and the Biologische Anstalt Helgoland (Germany) for providing Aplysia puncata and lab space as well as Dr. Bernadette Lucas and Dr. Anastasios Tsirpouchtsidis for the collection of ink. We are grateful to Dr. Christian Petzelt and Dr. Thomas F Meyer for valuable discussions. Dominique Khalil and Jana Söhlke are thanked for excellent technical assistance, Dr. Anna Walduck and Dr. Trent Fowler for carefully reading the manuscript and Luise Fehlig for help with the layout of the figures. This study was funded in part by the Bundesministerium für Bildung und Forschung to TR.

\section{References}

1. Nolen TG, Johnson PM, Kicklighter CE and Capo T (1995) Ink secretion by the marine snail Aplysia californica enhances its ability to escape from a natural predator. J. Comp. Physiol. Sens. Neural Behav. Physiol. 176: 239-254

2. Yamada K and Kigoshi $H$ (1997) Bioactive compounds from the sea hares of two genera: Aplysia and Dolabella. Bull. Chem. Soc. Jpn. 70: 1479-1489

3. Yamazaki M (1993) Antitumor and antimicrobial glycoproteins from sea hares. Comp. Biochem. Physiol. C. 105: 141-146

4. Petzelt C, Joswig G, Stammer H and Werner D (2002) Cytotoxic cyplasin of the sea hare, Aplysia punctata, cDNA cloning, and expression of bioactive recombinants in insect cells. Neoplasia 4: 49-59

5. Fiers W, Beyaert R, Declercq W and Vandenabeele P (1999) More than one way to die: apoptosis, necrosis and reactive oxygen damage. Oncogene 18: 7719-7730

6. Green DR (1998) Apoptotic pathways - the roads to ruin. Cell 94: 695-698

7. Kroemer G, Dallaporta B and Rescherigon M (1998) The mitochondrial death/ life regulator in apoptosis and necrosis. Ann. Rev. Physiol. 60: 619-642

8. Formigli L, Papucci L, Tani A, Schiavone N, Tempestini A, Orlandini GE, Capaccioli S and Orlandini SZ (2000) Aponecrosis: morphological and biochemical exploration of a syncretic process of cell death sharing apoptosis and necrosis. J. Cell Physiol. 182: 41-49

9. Szatrowski TP and Nathan CF (1991) Production of large amounts of hydrogen peroxide by human tumor cells. Cancer Res. 51: 794-798

10. Burdon RH (1995) Superoxide and hydrogen-peroxide in relation to mammalian-cell proliferation. Free Radic. Biol. Med. 18: 775-794

11. Benhar M, Engelberg D and Levitzki A (2002) ROS, stress-activated kinases and stress signaling in cancer. EMBO Rep. 3: 420-425

12. Benhar M, Dalyot I, Engelberg D and Levitzki A (2001) Enhanced ROS production in oncogenically transformed cells potentiates c-Jun N-termina kinase and p38 mitogen-activated protein kinase activation and sensitization to genotoxic stress. Mol. Cell. Biol. 21: 6913-6926 
13. Fujii $\mathrm{J}$ and Ikeda $Y$ (2002) Advances in our understanding of peroxiredoxin, multifunctional, mammalian redox protein. Redox Rep. 7: 123-130

14. Butterfield LH, Merino A, Golub SH and Shau H (1999) From Cytoprotection to tumor suppression: the multifactorial role of peroxiredoxins. Antiox. Redox Sig 1: $385-402$

15. Kinnula VL, Lehtonen S, Sormunen R, Kaarteenaho-Wiik R, Kang SW, Rhee SG and Soini Y (2002) Overexpression of peroxiredoxins I, II, III, V, and VI in malignant mesothelioma. J. Pathol. 196: 316-323

16. Noh DY, Ahn SJ, Lee RA, Kim SW, Park IA and Chae HZ (2001) Overexpression of peroxiredoxin in human breast cancer. Anticancer Res. 21 2085-2090

17. Johnstone RW, Ruefli AA and Lowe SW (2002) Apoptosis: a link between cancer genetics and chemotherapy. Cell 108: 153-164

18. Fleury C, Mignotte B and Vayssiere $\mathrm{JL}$ (2002) Mitochondrial reactive oxygen species in cell death signaling. Biochimie 84: 131-141

19. Thiede B, Siejak F, Dimmler C and Rudel T (2002) Prediction of translocation and cleavage of heterogeneous ribonuclear proteins and Rho guanine nucleotide dissociation inhibitor 2 during apoptosis by subcellular proteome analysis. Proteomics 2: 996-1006

20. Chao DT and Korsmeyer SJ (1998) Bcl-2 family - regulators of cell-death. Ann. Rev. Immunol. 16: 395-419

21. Lim YS, Cha MK, Yun CH, Kim HK, Kim K and Kim IH (1994) Purification and characterization of thiol-specific antioxidant protein from human red blood cell: a new type of antioxidant protein. Biochem. Biophys. Res. Commun. 199: 199-206

22. Prosperi MT, Apiou F, Dutrillaux B and Goubin G (1994) Organization and chromosomal assignment of two human PAG gene loci: PAGA encoding a functional gene and PAGB a processed pseudogene. Genomics 19: 236-241

23. Sauri H, Butterfield L, Kim A and Shau H (1995) Antioxidant function of recombinant human natural killer enhancing factor. Biochem. Biophys. Res. Commun. 208: 964-969

24. Kang SW, Chae HZ, Seo MS, Kim K, Baines IC and Rhee SG (1998) Mammalian peroxiredoxin isoforms can reduce hydrogen peroxide generated in response to growth factors and tumor necrosis factor-alpha. J. Biol. Chem. 273: 6297-6302

25. Konat $\mathrm{GW}$ (2003) $\mathrm{H}_{2} \mathrm{O}_{2}$-induced higher order chromatin degradation: a novel mechanism of oxidative genotoxicity. J. Biosci. 28: 57-60

26. Clement MV and Pervaiz S (2001) Intracellular superoxide and hydrogen peroxide concentrations: a critical balance that determines survival or death Redox. Rep. 6: 211-214

27. Suzuki H, Kumagai T, Goto A and Sugiura T (1998) Increase in intracellular hydrogen peroxide and upregulation of a nuclear respiratory gene evoked by impairment of mitochondrial electron transfer in human cells. Biochem. Biophys. Res. Commun. 249: 542-545

28. Dröge W (2002) Free radicals in the physiological control of cell function. Physiol. Rev. 82: 47-95

29. Thornberry NA and Lazebnik Y (1998) Caspases - enemies within. Science 281: $1312-1316$

30. Hampton MB and Orrenius S (1997) Dual regulation of caspase activity by hydrogen peroxide: implications for apoptosis. FEBS Lett. 414: 552-556

31. Borutaite V and Brown GC (2001) Caspases are reversibly inactivated by hydrogen peroxide. FEBS Lett. 500: 114-118

32. Hofmann B, Hecht HJ and Flohe L (2002) Peroxiredoxins. Biol. Chem. 383: 347-364

33. Yang KS, Kang SW, Woo HA, Hwang SC, Chae HZ, Kim K and Rhee SG (2002) Inactivation of human peroxiredoxin I during catalysis as the result of the oxidation of the catalytic site cysteine to cysteine-sulfinic acid. J. Biol. Chem. 277: 38029-38036

34. Woo HA, Chae HZ, Hwang SC, Yang KS, Kang SW, Kim K and Rhee SG (2003) Reversing the inactivation of peroxiredoxins caused by cysteine sulfinic acid formation. Science 300: 653-656

35. Chung YM, Yoo YD, Park JK, Kim YT and Kim HJ (2001) Increased expression of peroxiredoxin II confers resistance to cisplatin. Anticancer Res. 21: 1129-1133

36. Kim H, Lee TH, Park ES, Suh JM, Park SJ, Chung HK, Kwon OY, Kim YK, Ro HK and Shong M (2000) Role of peroxiredoxins in regulating intracellular hydrogen peroxide and hydrogen peroxide-induced apoptosis in thyroid cells. J. Biol. Chem. 275: 18266-18270

37. Gimbrone Jr MA, Cotranim RS and Folkman J (1974) Human vascular endothelial cells in culture. Growth and DNA synthesis. J. Cell Biol. 60: 673-684

38. Thiede B, Siejak F, Dimmler C, Jungblut PR and Rudel T (2000) A two dimensional electrophoresis database of a human Jurkat $T$-cell line. Electrophoresis 21: 2713-2720

39. Thiede B, Dimmler C, Siejak F and Rudel T (2001) Predominant identification of RNA-binding proteins in Fas-induced apoptosis by proteome analysis. J. Biol. Chem. 276: 26044-26050

40. Herrmann M, Lorenz HM, Voll R, Grunke M, Woith W and Kalden JR (1994) A rapid and simple method for the isolation of apoptotic DNA fragments. Nucleic Acids Res. 22: 5506-5507

41. Dahlgren C and Karlsson A (1999) Respiratory burst in human neutrophils. J. Immunol. Methods 232: 3-14 